\title{
Haloperidol moderately inhibits cardiovascular L-type calcium current
}

\author{
Bohumila Tarabová ${ }^{1}$, Marie Nováková ${ }^{2}$ and Lubica Lacinová ${ }^{1}$ \\ ${ }^{1}$ Institute of Molecular Physiology and Genetics, Centre of Excellence for Cardiovascular Research, Slovak Academy of \\ Sciences, Vlárska 5, 83334 Bratislava, Slovakia \\ ${ }_{2}^{2}$ Masaryk University, Faculty of Medicine, Department of Physiology, Komenského nám. 2, 66243 Brno, Czech Republic
}

\begin{abstract}
Effects of haloperidol on L-type Cavi 1.2 channel were studied. Calcium current was measured in whole cell patch-clamp using calcium as a charge carrier. Inhibition by haloperidol was investigated in $\mathrm{Ca}_{\mathrm{V}} 1.2$ channel natively expressed in rat cardiac myocytes and recombinant cardiac $\left(\mathrm{Ca}_{\mathrm{V}} 1.2_{\mathrm{a}}\right)$ and vascular $\left(\mathrm{Ca}_{\mathrm{V}} 1.2_{\mathrm{b}}\right)$ splice variants of the channel expressed in HEK 293 cells. Haloperidol inhibited L-type calcium current in a concentration-dependent manner with a threshold of $1 \mathrm{nmol} / \mathrm{l} .1 \mu \mathrm{mol} / \mathrm{l}$ haloperidol inhibited $20.6 \pm 3.6 \%$ of calcium current amplitude in cardiomyocytes, $25.4 \pm 2.6 \%$ of current amplitude through the $\mathrm{Ca}_{\mathrm{V}} 1.2_{\mathrm{b}}$ channel and $28.0 \pm 2.7 \%$ of current through the $\mathrm{Ca}_{\mathrm{V}} 1.2_{\mathrm{a}}$ channel. Inhibition was not accompanied by alteration of current waveform or by shift of current-voltage relation. In a current clamp haloperidol suppressed action potential generation. $1 \mu \mathrm{mol} / \mathrm{l}$ of the drug shortened the action potential duration in part of the cells and suppressed fully action potential in other cells. Moderate inhibition of the L-type calcium channels by haloperidol might cause shortening of action potential. Complete abolishment of action potential must have been mediated by inhibition of another, likely sodium channel.
\end{abstract}

Key words: Haloperidol - Cardiomyocytes - $\mathrm{Ca}_{\mathrm{V}} 1.2$ - Action potential - L-type calcium current

\section{Introduction}

Haloperidol (4-[4-(4-chlorophenyl)-4-hydroxy-1-piperidyl]-1-(4-fluorophenyl)-butan-1-on) is a butyrophenone derivate used in the treatment of psychiatric and neurological disorders such as schizophrenia, mania and delirium. Although this treatment has a high rate of success, it is also accompanied by adverse effects on nervous system including dyskinesia (Gil-ad et al. 2001) and by abnormal glucose metabolism (Baptista et al. 2002; Wirshing et al. 2002). Haloperidol affects also cardiovascular system causing heart arrhythmias, prolongation of QT-interval, torsade de pointes (Kriwisky et al. 1990; Hassaballa and Balk 2003) and sudden cardiac death (Mehta et al. 1979; Settle and Ayd 1983).

Mechanisms underlying cardiac side effects of haloperidol are not well understood. Concentrations commonly found

Correspondence to: Lubica Lacinová, Institute of Molecular Physiology and Genetics, Centre of Excellence for Cardiovascular Research, Slovak Academy of Sciences, Vlárska 5, 833 34 Bratislava, Slovakia

E-mail: lubica.lacinova@savba.sk in the plasma of treated patients vary between 10 and 200 nmol/l (Javaid et al. 1996; Jann et al. 1997; Ulrich et al. 1998; Kornhuber et al. 1999). Repeated high doses applied in early postoperative phase in agitated patients after general anesthesia may lead to peak plasma concentration of haloperidol in micromolar range. Such drug concentration was shown to alter electrical excitability of cardiomyocytes.

Drug effects on cardiac action potential depended on the type of preparation. In isolated guinea-pig papillary muscle, $1 \mu \mathrm{mol} / \mathrm{l}$ haloperidol prolonged and $10 \mu \mathrm{mol} / \mathrm{l}$ shortened the action potential duration (Arlock et al. 1978). In anesthetized dogs haloperidol consistently prolonged the repolarization phase of an action potential recorded by monophasic action potential catheters (Sugiyama et al. 2001; Rasty et al. 2004). Cardiac action potential measured from isolated rabbit ventricular muscle (Noguchi et al. 1999) was prolonged by 10 and $100 \mu \mathrm{mol} / \mathrm{l}$ of haloperidol, nevertheless, in some preparations $100 \mu \mathrm{mol} / \mathrm{l}$ haloperidol completely blocked the action potential generation.

Action potential waveform is determined by activity of voltage-dependent sodium, potassium and calcium channels. Sodium current forms an action potential upstroke. This cur- 
rent was potentiated by $30 \mathrm{nmol} / \mathrm{l}$ haloperidol in guinea-pig ventricular myocytes (Cheng et al. 2007). One to two decimal orders higher concentrations inhibited the sodium current with a half-maximal inhibition dose $\left(\mathrm{IC}_{50}\right)$ of $0.253 \mu \mathrm{mol} / \mathrm{l}$ and maximal current amplitude inhibition of $40 \%$ (Cheng et al. 2007). Ogata and Narahashi (1989) reported in the same preparation an $\mathrm{IC}_{50}$ of $7.0 \mu \mathrm{mol} / \mathrm{l}$ and complete inhibition of sodium current by $100 \mu \mathrm{mol} / \mathrm{l}$ haloperidol.

Multiple types of potassium channel shape repolarizing phase of an action potential. Haloperidol inhibited ATP-sensitive potassium channels with an $\mathrm{IC}_{50}$ of $1.6 \mu \mathrm{mol} / \mathrm{l}$ (Yang et al. 2004). hERG channels (Martin et al. 2004) were blocked more efficiently with an $\mathrm{IC}_{50}$ of $0.174 \mu \mathrm{mol} / \mathrm{l} .1 \mu \mathrm{mol} / \mathrm{l}$ haloperidol inhibited the transient outward potassium current in rat cardiomyocytes in frequency-dependent manner with maximal decrease of total potassium entry reaching $40 \%$ (Bebarova et al. 2006). All described effects may contribute to reported action potential prolongation, but not to shortening of action potential duration observed by other authors.

Plateau phase of mammalian cardiac action potential is codetermined by activity of L-type calcium channels. Interaction of haloperidol with these channels may contribute to observed drug effects on action potential duration. Until now, possible interaction of haloperidol with cardiac L-type calcium channel was not investigated. There are hints that such interaction may take place: i) haloperidol inhibited neuronal L-type calcium current in various preparations, e.g. in murine hippocampal neurons (Fletcher et al. 1994) and in rat intracardiac and superior cervical ganglia neurons (Zhang and Cuevas 2002); ii) haloperidol quaternary ammonium salt $\mathrm{N}$ - $n$-butyl haloperidol iodide $\left(\mathrm{F}_{2}\right)$ reduced L-type calcium current in rat cardiomyocytes with an $\mathrm{IC}_{50}$ of $1.19 \mu \mathrm{mol} / \mathrm{l}$ (Huang et al. 2003, 2007). Interaction of $\mathrm{F}_{2}$ with L-type calcium channels may differ from the effect of haloperidol itself because of the high polarity and the low lipid solubility of this synthesized compound. Therefore we decided to investigate the effect of haloperidol itself on cardiac L-type calcium current. We have used three experimental models: i) native cardiac L-type channel in rat ventricular myocytes; ii) recombinant cardiac $\mathrm{Ca}_{V} 1.2_{\mathrm{a}}$ channel; iii) recombinant smooth muscle $\mathrm{Ca}_{\mathrm{V}} 1.2_{\mathrm{b}}$ channel. Use of pure recombinant splice variants of the channel would reveal selectivity of the drug for one of channel subtypes. Such subtype specificity was described previously for dihydropyridines (Welling et al. 1993; Lacinova et al. 2000).

We have found that haloperidol in concentrations between $1 \mathrm{nmol} / \mathrm{l}$ and $10 \mu \mathrm{mol} / \mathrm{l}$ moderately inhibited L-type calcium current through calcium channels in all three models. Inhibition was independent of channel splice variants. Haloperidol was slightly more effective in recombinant system and less effective when current was activated by mock action potential. Further, $1 \mu \mathrm{mol} / \mathrm{l}$ haloperidol either decreased action potential duration or completely blocked action potential generation in cardiomyocytes.

\section{Materials and Methods}

\section{Cell preparation and transfection}

Cardiomyocytes were isolated from heart ventricles of adult male Wistar rats (weight 160-230 g). Animal handling complied with all requirements of the European Community Guide for the Care and Use of Laboratory Animals and the National Ethical Guidelines for the Use and Welfare of Laboratory Animals. Institutional ethics committee approved experimental protocols. Rats were anaesthetized with pentobarbital (10-20 mg/100 g body weight; Spofa, Czech Republic) with addition of heparin (0.2 ml per animal; Léčiva, Czech Republic). The heart was quickly removed and placed into a chilled Krebs-Henseleit solution $\left(5^{\circ} \mathrm{C}\right)$. Then, the aorta was cannulated and the heart was perfused using modified Langendorff apparatus with KrebsHenseleit solution $\left(37^{\circ} \mathrm{C}\right.$, cca $\left.1.2 \mathrm{mmol} / \mathrm{l} \mathrm{CaCl}_{2}\right)$ for $3 \mathrm{~min}$ to washout the blood. Next the perfusion was switched to calciumfree Krebs-Henseleit solution $\left(37^{\circ} \mathrm{C}\right)$ for $5 \mathrm{~min}$. Afterwards, the heart was perfused with Krebs-Henseleit solution containing collagenase enzyme (Liberase Blendzyme; Roche Diagnostics Corporation, Germany) in concentration of $0.1 \mathrm{mg} / \mathrm{ml}$. The digestion continued for approx. 10-20 min until heart became swollen and slightly pale. Digested heart was removed from the perfusion apparatus and placed into the Petri dish with Krebs-Henseleit solution containing albumin $(10 \mathrm{mg} / \mathrm{ml})$ with free nominal calcium concentration cca $7 \mu \mathrm{mol} / \mathrm{l}$. Heart atria were removed and ventricles were gently minced with scissors. Single myocytes were obtained by gentle mixing on the magnetic stirrer. The cell suspension was filtered through mull and centrifuged at approx. $500 \mathrm{rpm}$. Isolated myocytes were used in the electrophysiological experiments during 4-5 h after isolation.

HEK 293 cells were transiently transfected with pcDNA3 vectors containing cDNA encoding either cardiac $\alpha_{1 \mathrm{C}-\mathrm{a}}$ or smooth muscle $\alpha_{1 C-b}$ isoforms of the $\mathrm{Ca}_{\mathrm{V}} 1.2$ channel together with plasmids containing cDNA for auxiliary subunits $\beta_{2 \mathrm{a}}$ and $\alpha_{2} \delta$ at a DNA mass ratio $1: 1: 1$. The transfection was done by lipofection with Lipofectamine 2000 (Invitrogene, USA). Transfected cells were used for the electrophysiological experiments on days 2-3 after transfection. Nontransfected HEK 293 cell line was purchased from Deutsche Sammlung von Mikroorganismen und Zellkulturen, $\mathrm{GmbH}$ (Braunschweig, Germany). The cells were grown in Eagle's modified essential medium which contained 10\% (v/v) fetal calf serum and $100 \mathrm{U} / \mathrm{ml}$ penicillin-streptomycin at $37^{\circ} \mathrm{C}$ in a humidified atmosphere of air $/ \mathrm{CO}_{2} 95: 5$.

\section{Electrophysiology}

L-type calcium currents were recorded in whole-cell configuration of patch-clamp obtained by brief suction. Experiment was controlled by EPC-10 patch-clamp amplifier (HEKA Elec- 
tronic, Germany). The capacitance of the HEK 293 cells ranged between 10 and $30 \mathrm{pF}$. Cardiomyocytes had the capacitance between 90 and $200 \mathrm{pF}$. The series resistance ranged between 2 and $5 \mathrm{M} \Omega$. Both capacitance and series resistance were compensated up to $70 \%$ by built-in circuits of the EPC-10 amplifier. Patch pipettes were made from borosilicate glass (Sutter Instrument, USA). When filled with intracellular solution their input resistance ranged from 1.8 to $2.5 \mathrm{M} \Omega$. Extracellular and intracellular solutions used in individual experiments are listed in Tables 1 and 2. pH of all solutions was adjusted to 7.4. Osmolarity of the internal solutions was approx. $300 \mathrm{mOsm}$. Osmolarity of the external solutions was adjusted by adding glucose so that its final value was 2-3 mOsm lower than the osmolarity of internal solution.

The effect of haloperidol on calcium current amplitude through the $\mathrm{Ca}_{\mathrm{V}} 1.2$ channels was evaluated from amplitudes of inward calcium current activated by the series of $100 \mathrm{~ms}$ long depolarizing pulses applied with the frequency $0.2 \mathrm{~Hz}$ from a holding potential $(H P)$ of $-60 \mathrm{mV}$ for cardiomyocytes and -80 $\mathrm{mV}$ for HEK 293 cells to a membrane potential corresponding to the peak of respective current-voltage $(I-V)$ relation. $I-V$ relations were measured by series of $100 \mathrm{~ms}$ long depolarizing pulses elicited every $5 \mathrm{~s}$ from a $H P$ of $-60 \mathrm{mV}$ to membrane potentials between $-70 \mathrm{mV}$ and $+70 \mathrm{mV}$ (cardiomyocytes) or from $H P$ of $-80 \mathrm{mV}$ to membrane potentials between $-50 \mathrm{mV}$ and $+90 \mathrm{mV}$ (HEK 293 cells) with an increment of $+10 \mathrm{mV}$. Haloperidol effect on cardiac action potential was investigated in the current clamp mode by series of $5 \mathrm{~ms}$ long depolarizing current pulses applied from constant membrane current ranging from $-10 \mathrm{pA}$ to $-100 \mathrm{pA}$ every $5 \mathrm{~s}$. Amplitude of current pulse ranged from +700 to $+900 \mathrm{pA}$ and was estimated as a 1.5 -fold of the amplitude of threshold pulse required for generation of an action potential in each cell. Pre-recorded action potential waveform was used as a depolarizing stimulus for measurement of ion currents activated by an action potential in myocytes. An action potential waveform was applied every $10 \mathrm{~s}$.

Haloperidol (Sigma, Germany) was prepared as $1 \mathrm{mmol} / \mathrm{l}$ stock solution in dimethylsulphoxide (DMSO; Sigma, Germany) every week and stored at room temperature. Maximal concentration of DMSO used in tested solution was 10 $\mu \mathrm{mol} / \mathrm{l}$. This concentration did not affect L-type calcium current amplitude (data not shown). Final concentrations were prepared prior to the experiment by dilution in the external solutions. Extracellular solutions were exchanged by a gravity driven perfusion system. Tetrodotoxin (Alomone Labs. Ltd., Israel) in the concentration of $10 \mu \mathrm{mol} / \mathrm{l}$ was used in the experiments for measurement of calcium currents in cardiomyocytes to block the sodium current.

\section{Data analysis}

Data were recorded using a HEKA Pulse 8.5 and Patchmaster 1.2 and analyzed with HEKA Pulsefit 8.5, Fitmaster 2.2 and
Table 1. Composition of extracellular solutions. Composition of experimental solutions used for measurement of calcium current in transfected and non-transfected HEK 293 cells, for measurement of calcium current in myocytes ( $\mathrm{Myo} \mathrm{I}_{\mathrm{Ca}}$ ), for measurement of action potential of myocytes (Myo AP) and for measurement of currents activated by action potential ( $\mathrm{Myo} \mathrm{I}_{\mathrm{Ca}}$ stim $\mathrm{AP}$ ). All concentrations are listed in $\mathrm{mmol} / \mathrm{l}$

\begin{tabular}{|c|c|c|c|c|}
\hline & \multicolumn{4}{|c|}{ Extracellular solutions } \\
\hline & HEK 293 & Myo $\mathrm{I}_{\mathrm{Ca}}$ & Myo AP & $\begin{array}{l}\text { Myo I } \mathrm{Ca} \\
\text { stim AP }\end{array}$ \\
\hline $\mathrm{NaCl}$ & 95 & 145 & 130 & - \\
\hline $\mathrm{CaCl}_{2}$ & 30 & 2 & 2 & 2 \\
\hline Glucose & 5 & 5 & 5 & 5 \\
\hline $\mathrm{CsCl}$ & - & 5 & - & 4 \\
\hline $\mathrm{MgCl}_{2}$ & 1 & 1 & 1 & 1 \\
\hline HEPES & 10 & 10 & 10 & 10 \\
\hline TEA-Cl & - & - & - & 130 \\
\hline $\mathrm{KCl}$ & - & - & 4 & - \\
\hline
\end{tabular}

Table 2. Composition of intracellular solutions. Composition of experimental solutions used for measurement of calcium current in transfected and non-transfected HEK 293 cells, for measurement of calcium current in myocytes $\left(\mathrm{Myo} \mathrm{I}_{\mathrm{Ca}}\right.$ ), for measurement of action potential of myocytes (Myo AP) and for measurement of currents activated by action potential (Myo $\mathrm{I}_{\mathrm{Ca}}$ stim $\mathrm{AP}$ ). All concentrations are listed in $\mathrm{mmol} / \mathrm{l}$

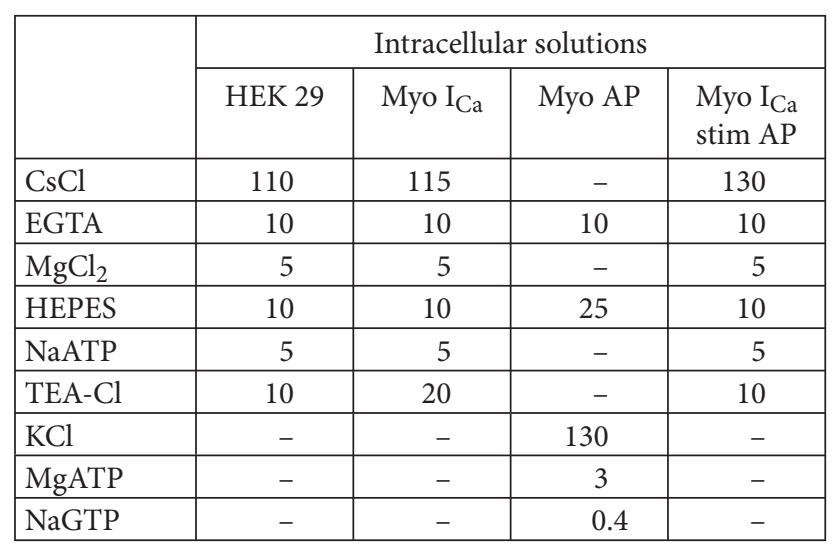

Origin 7.5 software. Capacity transients and series resistance were compensated on-line by built-in procedures of an EPC-10 amplifier. The experimental values are presented as mean \pm S.E.M. Significance of the observed effects was assessed by paired or unpaired Student's $t$-test. Recorded currents were off-line corrected for linear leak current component calculated according the Eq. (1):

$$
I_{s u b}=I_{V}-\frac{V}{H P} I_{H P}
$$


where $I_{\text {sub }}$ is leak-subtracted current, $I_{V}$ is nonsubtracted current measured at membrane potential $V, H P$ is the holding membrane patential and $I_{H P}$ is the averaged membrane current measured at the $H P$, i.e. actual linear component of leak current.

In part of experiments on cardiomyocytes run-down of the L-type calcium current amplitude with a monoexponential time course was observed. Calcium current amplitudes were corrected for such run-down according to the Eq. (2):

$$
I_{\text {corrected }}=I_{\text {measured }}+\left(I_{\max }-\left(y_{0}+A_{1} \cdot \exp \left(\frac{t}{\tau}\right)\right)\right)
$$

where $I_{\text {corrected }}$ is corrected current amplitude, $I_{\text {measured }}$ is a current amplitude measured during experiment, $I_{\max }$ is maximal current amplitude measured at the beginning of current recording, $y_{0}$ is steady-state current amplitude to which current amplitude converged during run-down, $A_{1}$ is amplitude of monoexponential curve in $t=0, \tau$ is its time constant and $t$ is time.

\section{Results}

Effects of haloperidol on L-type calcium current in rat ventricular cardiomyocytes

First, we have established the effect of haloperidol on native L-type calcium current in cardiac myocytes. In these and all following experiments single haloperidol concentration was applied to each investigated cell. Extracellularly applied nanomolar concentrations (1-3 nmol/l) showed only minimal inhibitory action on calcium current in cardiomyocytes. $1 \mathrm{nmol} / \mathrm{l}$ of ha-
A

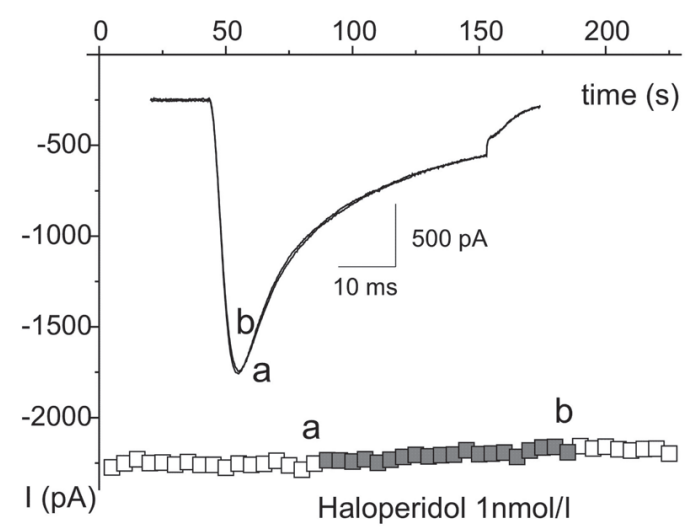

C

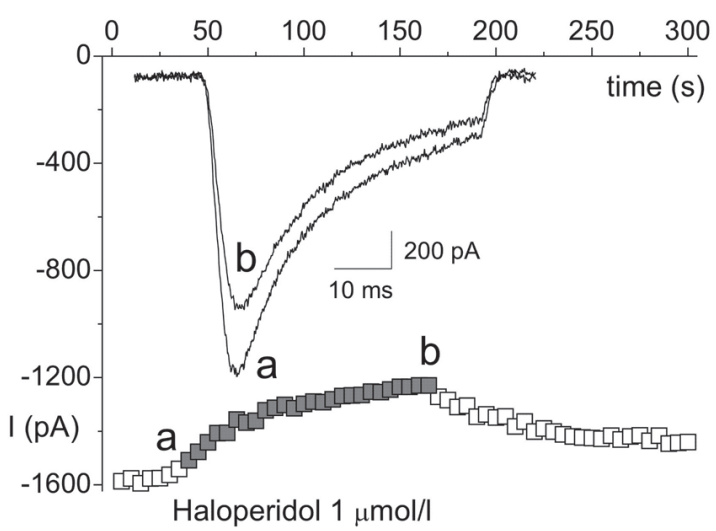

B

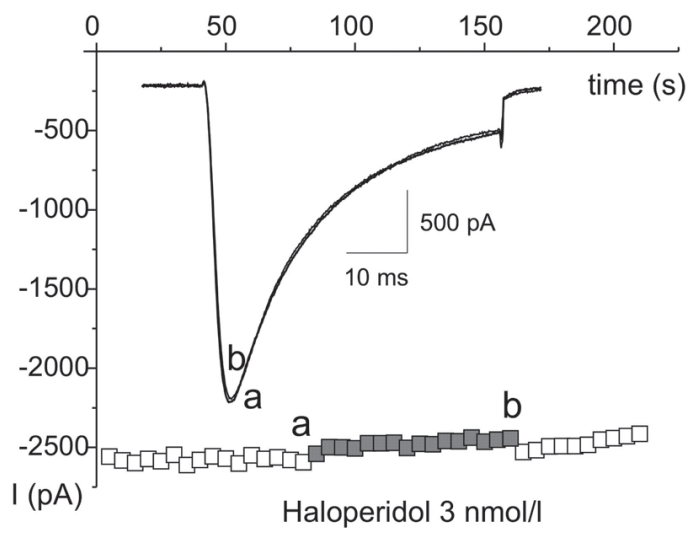

D

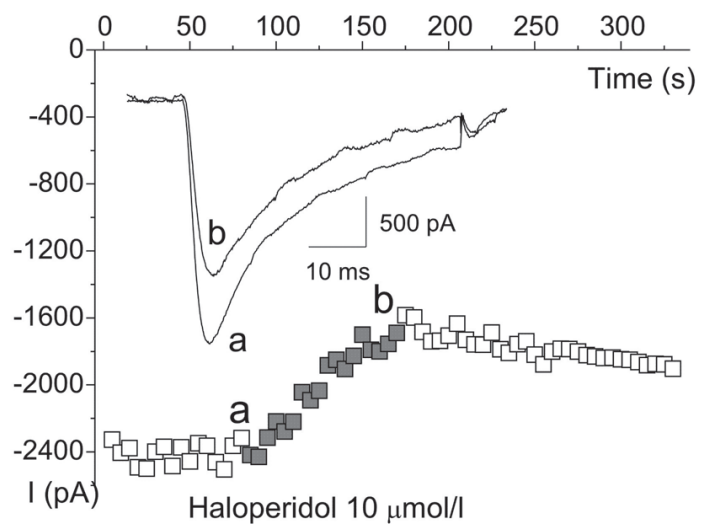

Figure 1. Examples of time courses of the inhibition of L-type calcium current amplitude in cardiomyocytes by $1 \mathrm{nmol} / \mathrm{l}(\mathrm{A}), 3 \mathrm{nmol} / \mathrm{l}$ (B), $1 \mu \mathrm{mol} / \mathrm{l}(\mathrm{C})$ and $10 \mu \mathrm{mol} / \mathrm{l}(\mathrm{D})$ of haloperidol. Drug application is indicated by filled squares. Current traces recorded before (indicated by a letter a) and during (indicated by a letter b) application of haloperidol are shown in insets. 
loperidol inhibited $2.6 \pm 0.7 \%(n=5$, Fig. $1 \mathrm{~A})$ of calcium current amplitude and $3 \mathrm{nmol} / \mathrm{l}$ concentration reduced calcium current by $5.6 \pm 1.4 \%(n=8$, Fig. $1 \mathrm{~B})$. Haloperidol in $1 \mu \mathrm{mol} / \mathrm{l}$ concentration inhibited $20.6 \pm 3.6 \%(n=7$, Fig. $1 \mathrm{C})$ of calcium current amplitude in isolated rat ventricular myocytes. The highest tested concentration of haloperidol $(10 \mu \mathrm{mol} / \mathrm{l})$ reduced the calcium current amplitude in myocytes by $28.0 \pm 1.9 \%(n=6$, Fig. 1D). The inhibition of the current was partially reversible upon washout of the drug. Extent of inhibition of the current amplitude was independent of the amplitude of depolarizing pulse, as documented in raw $I$ - $V$ curves on the Fig. $2 \mathrm{~A}$ and in normalized $I-V$ curves on the Fig. 2B. Effect of haloperidol in concentrations from 1 to $10 \mu \mathrm{mol} / \mathrm{l}$ on calcium current amplitude in cardiomyocytes is summarized in Fig. 2C. Even at $10 \mu \mathrm{mol} / \mathrm{l}$ haloperidol was not capable of inhibiting $50 \%$ of current amplitude. Higher drug concentrations were not tested because of its limited solubility and physiological irrelevance of such concentrations. Short range of current inhibition does not allow reliable fit of experimental data by the Hill equation. Extrapolation of experimental data would yield an approximate $\mathrm{IC}_{50}$ of $0.5 \mathrm{mmol} / \mathrm{l}$ and a Hill coefficient of 0.22 . Such shallow dose-dependence suggests multiple interaction sites on the same channel and/or inhibition by obstruction of conductive pore by several molecules of drug rather than binding to a specific binding site.

\section{Effect of haloperidol on L-type calcium channel splice variants expressed in HEK 293 cells}

Interaction of some organic L-type calcium channel blockers with the channel may be splice variant-specific (for review, see Lacinová 2005). To see if this may be a case also for haloperidol we tested its effect on calcium current through $\mathrm{Ca}_{\mathrm{V}} 1.2_{\mathrm{b}}$ smooth muscle and $\mathrm{Ca}_{\mathrm{V}} 1.2_{\mathrm{a}}$ cardiac isoforms of the $\mathrm{Ca}_{\mathrm{V}} 1.2$ channel transiently expressed in HEK 293 cells together with auxiliary $\beta_{2}$ and $\alpha_{2} \delta$ subu-
A

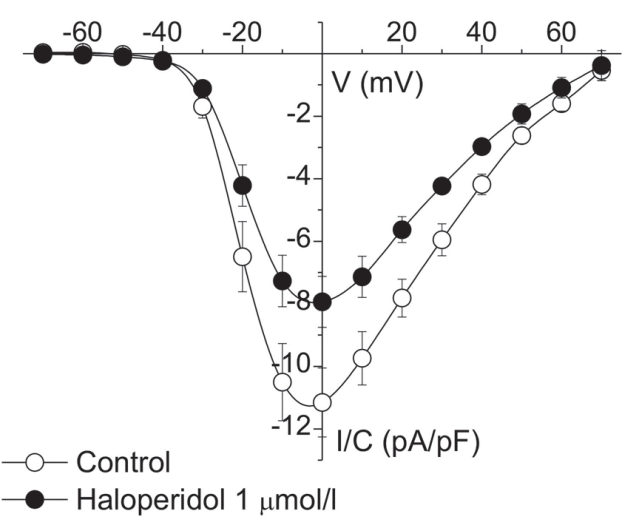

B

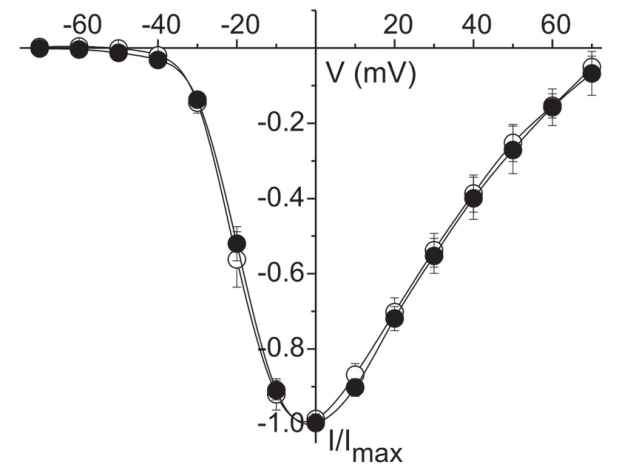

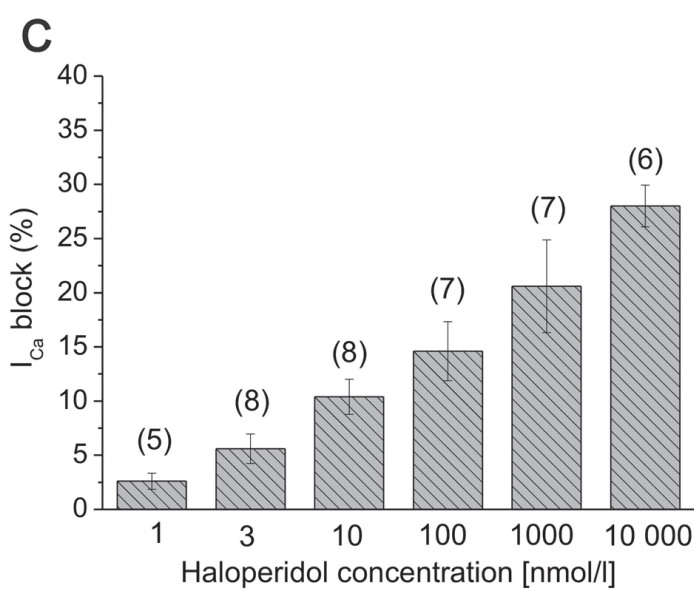

Figure 2. A. $I-V$ relations for L-type calcium current in myocytes measured by series of depolarization pulses from $H P-60 \mathrm{mV}$ to indicated voltages before (open circles) and during application of $1 \mu \mathrm{mol} / \mathrm{l}$ haloperidol ( $n=5$, filled circles). B. $I-V$ relations from Fig. $2 \mathrm{~A}$ normalized with respect to the maximal current amplitude. C. Inhibition of calcium current by haloperidol concentrations. Numbers in brackets represent number of cells. 
nits. Because of low expression level of the recombinant $\mathrm{Ca}_{V} 1.2$ channels, the concentration of calcium ions in bath solution was increased to $30 \mathrm{mmol} / \mathrm{l}$ in order to enhance the current amplitude. Due to the changed surface charge screening effect of calcium ions $I-V$ relations were shifted by about $+30 \mathrm{mV} .1 \mu \mathrm{mol} / \mathrm{l}$ haloperidol caused $25.4 \pm 2.6 \%$ $(n=13)$ inhibition of current through the $\mathrm{Ca}_{\mathrm{V}} 1.2_{\mathrm{b}}$ smooth muscle isoform and $28.0 \pm 2.7 \%(n=7)$ inhibition of current through the $\mathrm{Ca}_{\mathrm{V}} 1.2_{\mathrm{a}}$ cardiac isoform of the $\mathrm{Ca}_{\mathrm{V}} 1.2$ channel (Fig. 3A,B). This effect was readily reversible and was not accompanied by shift of the peak of $I-V$ relations (Fig. 3C,D).

\section{Effect of haloperidol on action potential in cardiomyocytes}

Calcium current through the L-type calcium channel in cardiomyocytes participates in shaping the plateau phase of action potential. We examined how haloperidol affects an action potential in rat ventricular cardiomyocytes triggered by rectangular $5 \mathrm{~ms}$ long current pulse with suprathreshold
A

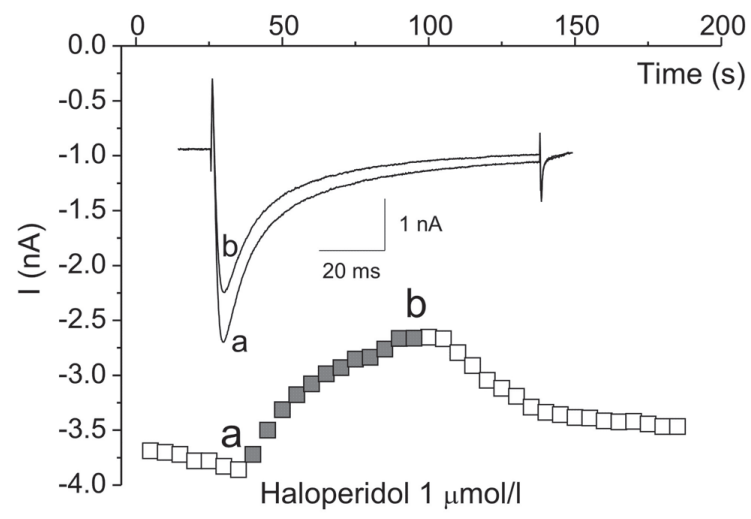

C

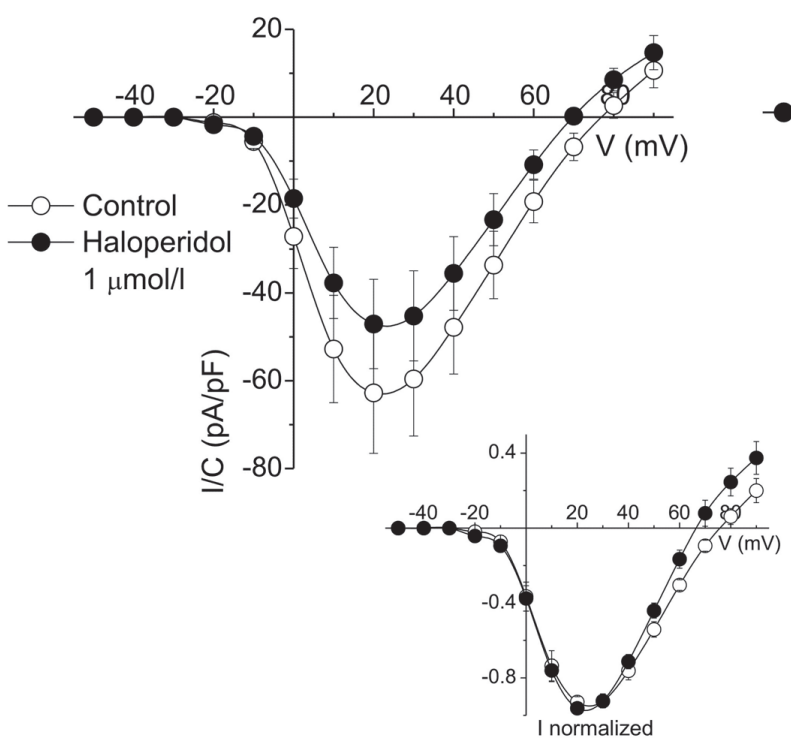

B

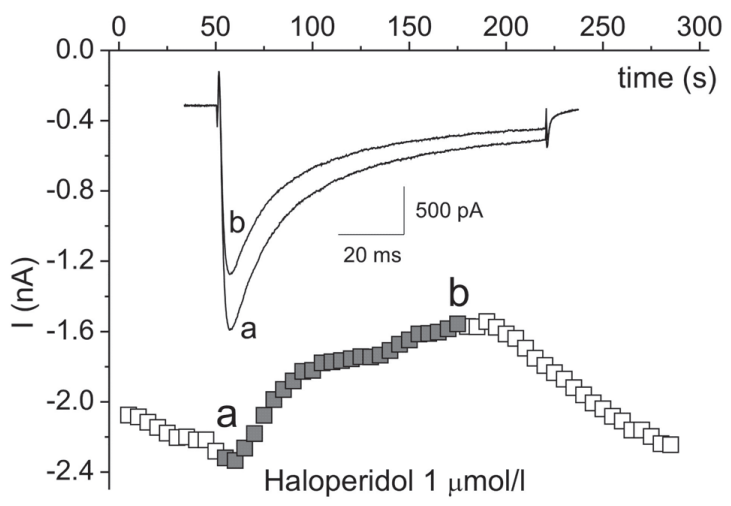

D

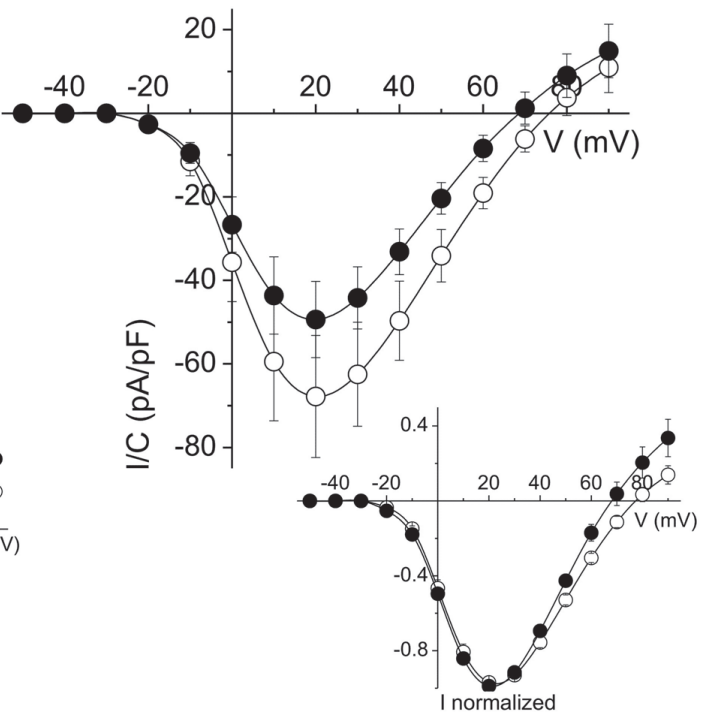

Figure 3. Time courses of inhibition of peak current through smooth muscle $\mathrm{Ca}_{V} 1.2_{\mathrm{b}}(\mathrm{A})$ and cardiac $\mathrm{Ca}_{\mathrm{V}} 1.2_{\mathrm{a}}(\mathrm{B})$ isoforms of the Cav1.2 channel by $1 \mu \mathrm{mol} / \mathrm{l}$ haloperidol. Presence of the drug is indicated by filled squares. Current traces recorded under control conditions (indicated by a letter a) and in the presence of haloperidol (indicated by a letter b) are shown in insets. I- $V$ relations for L-type calcium current through smooth muscle $(\mathrm{C}, n=8)$ and cardiac $(\mathrm{D}, n=8) \mathrm{Ca}_{\mathrm{V}} 1.2$ channel isoforms measured by the series of depolarization pulses from $H P-80 \mathrm{mV}$ to indicated voltages before (open circles) and during application of $1 \mu \mathrm{mol} / \mathrm{l}$ haloperidol (filled circles). Corresponding $I-V$ relations normalized with respect to the maximal current amplitude are shown in the insets to both panels. 
amplitude (for details, see Materials and Methods). Extent of haloperidol effect was variable. In part of investigated myocytes $1 \mu \mathrm{mol} / \mathrm{l}$ haloperidol shortened the action potential duration ( $n=13$; Fig. $4 \mathrm{~A})$ with partial reversibility. In other cardiomyocytes action potential was fully blocked by the same haloperidol concentration $(n=5$; Fig. $4 \mathrm{~B})$. This effect was readily reversible upon washout (Fig. 4B).

During these experiments myocytes were superfused by haloperidol until maximal effect was reached. Total block of an action potential was established faster (46 $\pm 6 \mathrm{~s}, n=8)$. In this subpopulation of myocytes width of action potential after haloperidol washout relative to action potential width measured under the control conditions was $1.04 \pm 0.06$. When haloperidol decreased the action potential width the new steady-state was established more slowly $(111 \pm 7 \mathrm{~s}$, $n=9$ ). In this subpopulation of myocytes relative action potential width after haloperidol washout was $0.78 \pm 0.06$. Incomplete washout after longer exposure may be caused
A
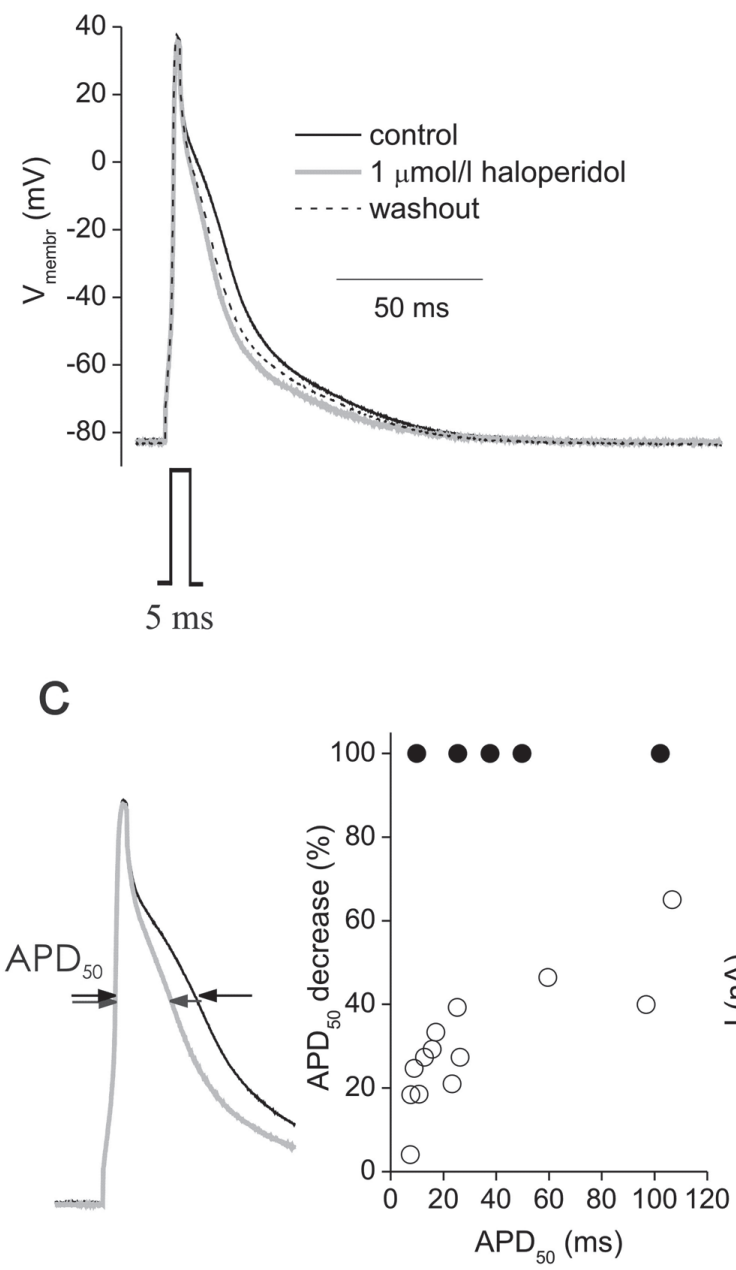

B

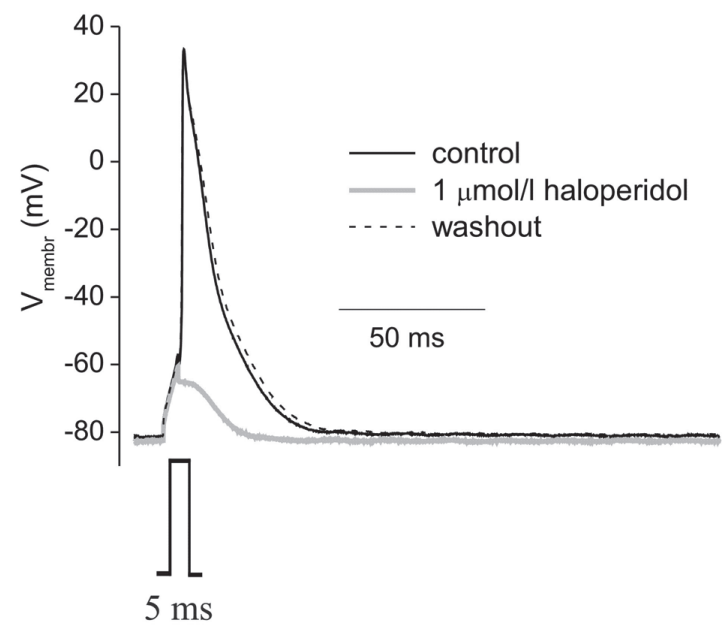

D

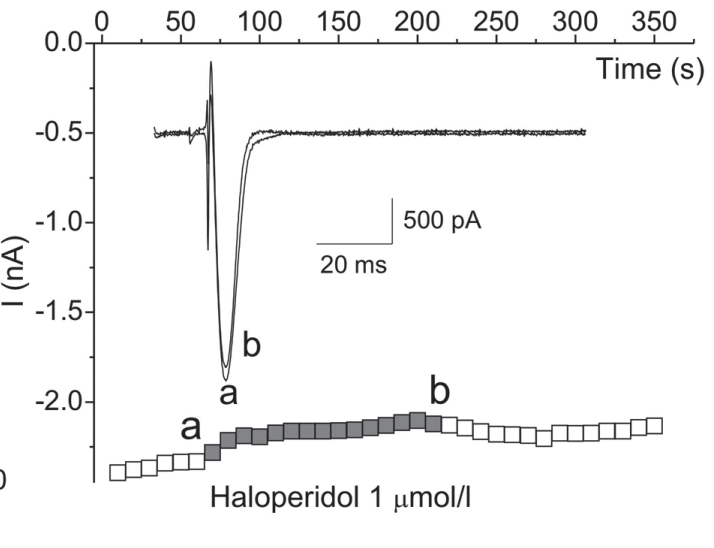

Figure 4. Action potential in cardiomyocytes activated by $5 \mathrm{~ms}$ rectangular pulse recorded in control conditions (solid black line), in the presence of $1 \mu \mathrm{mol} / \mathrm{l}$ haloperidol (solid grey line) and after wash out with bath solution (dashed black line). A. Example of recording from a cell in which haloperidol shortened the action potential duration measured at $50 \%$ of the action potential amplitude $\left(\mathrm{APD}_{50}\right)$. B. Example of recording from a cell in which action potential was completely blocked during application of $1 \mu \mathrm{mol} / \mathrm{l}$ haloperidol. C. Relative decrease in $\mathrm{APD}_{50}$ in the presence of haloperidol was drawn versus initial $\mathrm{APD}_{50}$ evaluated under the control conditions. Filled circles represent full inhibition of an action potential during haloperidol application. Open circles symbolize cardiomyocytes with shortened $\mathrm{APD}_{50}$. D. Time course of inhibition of amplitude of the calcium current activated by an action potential waveform in myocytes by $1 \mu \mathrm{mol} / \mathrm{l}$ haloperidol. Filled squares indicate presence of drug. Examples of current traces recorded under the control conditions (indicated by a letter a) and in the presence of haloperidol (indicated by a letter b) are shown in the inset. 
by accumulation of lipophilic agent haloperidol within cell membrane.

Variability of haloperidol effect on an action potential could be caused by variability in the expression of various voltage-activated ion channels throughout myocardium. Relative expression of individual voltage-activated channels is reflected in action potential shape and duration. It is known that the action potential duration varies the localization of myocytes in the layers of the heart tissue. Action potential of subepicardial myocytes has the shortest duration and action potential of midmyocardial myocytes is the widest (for review, see Antzelevitch 2007) due to variable expression of individual types of voltage-activated ion channels. If variable expression of ion channels was the cause of variable extent of haloperidol effect, it should correlate with an action potential width. We evaluated the dependence of haloperidol effect on action potential duration measured at $50 \%$ of the action potential amplitude $\left(\mathrm{APD}_{50}\right)$. Solid circles represent cardiomyocytes with fully blocked action potential during application of $1 \mu \mathrm{mol} / \mathrm{l}$ haloperidol while open circles represent cardiomyocytes with shortened action potential length (Fig. 4C). Apparently, haloperidol was able to fully block action potential generation independent of an action potential shape.

Effects on action potential shape are mediated by interaction with voltage-dependent channels, which are activated during action potential generation. Time course of inward calcium current during an action potential differs from that activated by rectangular voltage pulse. Therefore we tested the effect of haloperidol on calcium current activated by prerecorded action potential waveform. $1 \mu \mathrm{mol} / \mathrm{l}$ haloperidol inhibited $5.8 \pm 0.8 \%(n=8)$ of calcium current amplitude under these conditions (Fig. 4D). Corresponding current traces in the control conditions and during haloperidol application are shown in inset of Fig. 4D.

\section{Inhibition of cardiac sodium current by haloperidol}

Moderate inhibition of the cardiac L-type calcium channel cannot account for observed complete abolishment of cardiac action potential. Previously reported inhibition of sodium current in guinea-pig cardiomyocytes (Ogata and Narahashi 1989; Cheng et al. 2007) could be responsible for this effect. Therefore we attempted to confirm this observation in our model. To mimic physiological conditions, sodium current was activated by pre-recorded action potential waveform. The same solutions as listed for calcium current activated by action potential waveform were used except that tetradotoxin was omitted from the bath solution. $1 \mu \mathrm{mol} / 1$ of haloperidol inhibited on average $6.7 \pm 1.8 \%(n=6)$ of the current amplitude and $10 \mu \mathrm{mol} / \mathrm{l}$ inhibited $63.4 \pm 3.4 \%$ ( $n=10$ ) of the current amplitude (Fig. 5). Inhibition extent was similar to that reported on guinea-pig myocytes (Cheng et al. 2007; Ogata and Narahashi 1989).

\section{Discussion}

Haloperidol has been successfully used in the treatment of various psychosis, agitated states and deliria for more than half of century. Although it has been more recently replaced by novel drugs with lesser side effect, its therapeutical potential is still regarded as very good. It is quite often used in the management of numerous behavioural problems in patients after general anaesthesia. Drug concentrations commonly found in the plasma of schizophrenia patients range between 10 and $100 \mathrm{nmol} / \mathrm{l}$ ( Javaid et al. 1996; Jann et al. 1997; Ulrich et al. 1998). Study of Kornhuber et al. (1999) showed that haloperidol is accumulated in the brain of patients even in higher concentration, approx. $0.2 \mu \mathrm{mol} / \mathrm{l}$. Furthermore,
A

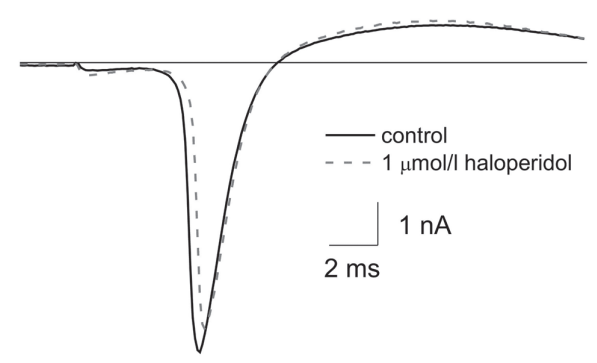

B

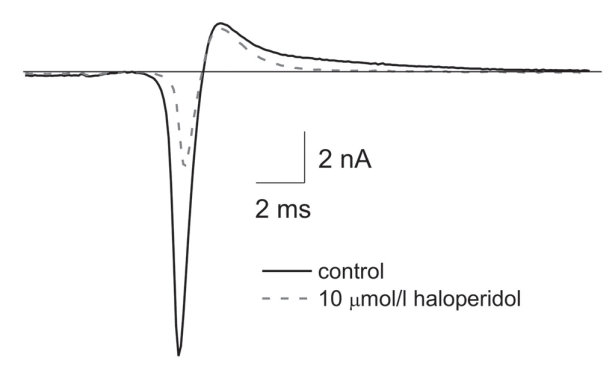

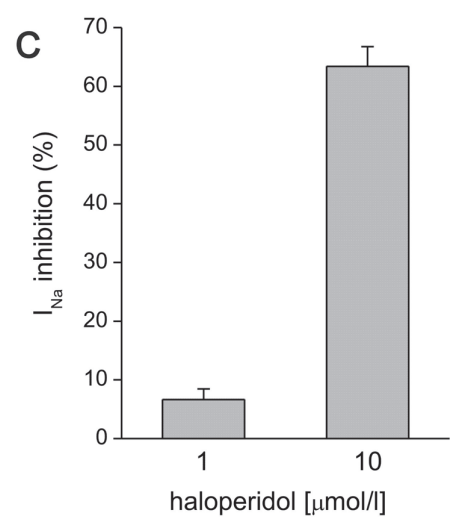

Figure 5. Inhibition of sodium current activated by an action potential waveform in cardiac ventricular myocyte by $1 \mu \mathrm{mol} / \mathrm{l}(\mathrm{A})$ and 10 $\mu \mathrm{mol} / \mathrm{l}$ (B) of haloperidol. Currents recorded under the control conditions are shown as solid black lines, while dashed gray lines represent current in the presence of haloperidol. C. Inhibition of sodium current amplitude demonstrated in panels A and B was averaged from 6 cells $(1 \mu \mathrm{mol} / \mathrm{l})$ and from 10 cells $(10 \mu \mathrm{mol} / \mathrm{l})$. 
when used in patients after general anaesthesia, e.g. in early postoperative phase, repeated high dose of haloperidol is applied. The plasmatic level of the drug can within short time reach relatively high level up to micromolar range.

Aim of this study was to reveal possible contribution of haloperidol-mediated inhibition of the L-type calcium channel to its cardiac side effects. Previously, the effect of haloperidol on L-type calcium current was demonstrated in neuronal tissues, e.g. cultured hippocampal neurons (Fletcher et al. 1994), or in immortalized cell lines, e.g. PC12 cells (Ito et al. 1996). Huang et al. $(2003,2007)$ used rat cardiac myocytes in their experiments, nevertheless, instead of haloperidol they used its quaternary ammonium salt derivative with different chemical properties.

In presented work, we investigated the interaction of haloperidol with L-type calcium current in isolated cardiomyocytes. This study was complemented by the study of recombinant $\mathrm{Ca}_{\mathrm{V}} 1.2_{\mathrm{a}}$ and $\mathrm{Ca}_{\mathrm{V}} 1.2_{\mathrm{b}}$ channels expressed in HEK 293 cells. Cardiomyocytes enabled study of the channel in its natural environment where the signaling pathways are largely preserved. Expression system allowed investigating the direct effect of haloperidol on current mediated by pure smooth muscle or cardiac isoforms of the $\mathrm{Ca}_{\mathrm{V}} 1.2$ channel, which may possess different affinity towards calcium channel blockers (for review, see Lacinová 2005).

In our experiments, $1 \mu \mathrm{mol} / \mathrm{l}$ haloperidol inhibited L-type calcium current in order of efficiency $\mathrm{Ca}_{\mathrm{V}} 1.2_{\mathrm{a}}$ isoform $>$ $\mathrm{Ca}_{\mathrm{V}} 1.2 \mathrm{~b}$ isoform $>\mathrm{Ca}_{\mathrm{V}} 1.2$ current in cardiomyocytes $(28.0$ $\pm 2.7 \%, 25.4 \pm 2.6 \%, 20 \pm 3.6 \%$, respectively). These differences were not statistically significant. Therefore we concluded that interaction of haloperidol with cardiovascular L-type calcium channel is independent of channel splice variant. The affinity of haloperidol towards cardiac and/or vascular splice variant of the $\mathrm{Ca}_{\mathrm{V}} 1.2$ channel in cardiac preparation as well as in expression system was slightly smaller than its affinity to neuronal $\mathrm{Ca}_{V} 1.2$ channel, which was inhibited with an $\mathrm{IC}_{50}$ of $16 \mu \mathrm{mol} / \mathrm{l}$ (Fletcher et al. 1994) and $20 \mu \mathrm{mol} / \mathrm{l}$ (Ito et al. 1996) in cultured hippocampal neurons and PC12 cells, respectively.

Haloperidol $(1 \mu \mathrm{mol} / \mathrm{l})$ did alter neither the shape of $I-V$ relation nor its position along the voltage axis in our experiments. Same lack of effect of haloperidol on $I-V$ relation was reported for L-type calcium current in PC12 cells (Ito et al. 1996). Together with unaltered current waveform these observations rule out possible state-dependent interaction between haloperidol and the calcium channel (Lacinova and Hofmann 1998).

In most experiments, including those reported here, the inhibition of calcium current was reversible upon washout (Fletcher et al. 1994; Ito et al. 1996; Huang et al. 2003, 2007). Recovery of calcium current amplitude upon washout was more effective in HEK 293 cells expressing recombinant Ca 1.2 channels and in PC12 cells than in cardiomyocytes.
L-type calcium channels in cardiomyocytes are localized in T-tubules, which represent deep invaginations of plasma membrane. This localization could limit both the access and the washout of haloperidol in cardiomyocytes and may explain not only hampered reversibility of haloperidol effect but also its lower blocking efficacy when compared to HEK 293 cells.

Quaternary ammonium salt derivative of haloperidol, $\mathrm{F}_{2}$ blocked cardiac L-type calcium channel, too. $1 \mu \mathrm{mol} / \mathrm{l}$ of $\mathrm{F}_{2}$ inhibited more than $70 \%$ of L-type calcium current amplitude in rat ventricular myocytes independent of the amplitude of depolarizing pulse (Huang et al. 2003, 2007). This drug was moderately more effective calcium channel blocker than haloperidol. In contrast to lipophilic haloperidol used in our experiments, $\mathrm{F}_{2}$ was designed to have low lipid solubility (Huang et al. 2003). Therefore, its mode and/or site of action may differ and this difference could account for higher blocking efficiency of $\mathrm{F}_{2}$.

Altogether, these observations document that haloperidol in concentrations corresponding to the upper limit of clinically relevant plasma peak levels is mild to moderate blocker of the L-type calcium channel. As L-type calcium channels participate in cell depolarization during the plateau of cardiac action potential, shortening of an action potential may be expected upon their inhibition. Indeed, we have observed such shortening. In our experiments, $1 \mu \mathrm{mol} / \mathrm{l}$ of haloperidol suppressed cardiac action potential up to its complete inhibition. This observation is similar to that reported by Arlock et al. (1978) for isolated guinea-pig papillary muscle in which $10 \mu \mathrm{mol} / \mathrm{l}$ of haloperidol caused decrease in $\mathrm{APD}_{50}$ and decrease in action potential amplitude. Nevertheless, the same author (Arlock et al. 1978) reported also widening of action potential length by low haloperidol concentrations. Such contradictory effects may be caused by the complex interplay of various effects of haloperidol on different ion channels expressed in investigated preparations.

In part of studied myocytes, haloperidol was capable of abolishing generation of an action potential. First, we hypothesized that this effect correlates with myocytes origin from specific subregion of left ventricle. It is known that cardiomyocytes originating from epicardial, myocardial and endocardial myocytes differ in expression of voltageactivated ion channels, which results in different shape of an action potential (Antzelevitch et al. 1991; Natali et al. 2002). Nevertheless, in such case haloperidol effect on an action potential should correlate with an action potential half-width and we did not observe such correlation.

Complete inhibition of cardiac action potential by haloperidol was reported (Noguchi et al. 1999) for rabbit ventricular muscle. Even if L-type calcium current may contribute to the membrane depolarization necessary for an action potential upstroke (Lacinova et al. 2008), its full abolishment suggest involvement of sodium current inhi- 
bition. Indeed, micromolar concentrations of haloperidol inhibited sodium current activated in guinea-pig ventricular myocytes (Ogata and Narahashi 1989), in retinal ganglia (Ito et al. 1996), in human atrial myocytes (Crumb et al. 2006), or in rat ventricular myocytes (present work). We suggest that inhibition of sodium current by haloperidol may cause "yes or no"-type of block of an action potential and that the concentration of $1 \mu \mathrm{mol} / \mathrm{l}$ lies just around the threshold for this effect causing observed cell-to-cell variation.

While the inhibition of L-type calcium current together with inhibition of outward potassium currents (Martin et al. 2004; Yang et al. 2004; Bebarova et al. 2006) may be responsible for shortening of an action potential observed in part of the investigated cardiomycytes, inhibition of sodium current reported also in this manuscript can explain complete abolishment of action potential observed in another part of investigated cardiomycytes. Altogether, we may conclude that cardiovascular side effects of haloperidol are not primarily induced by its interaction with the voltage-gated calcium channels, nevertheless, it may partly contribute to them. We suppose that negative side effects observed during haloperidol therapy are caused mainly by inhibition of other voltage-gated channels in cardiomyocytes, in the first instance, sodium channels.

Acknowledgements. We are grateful to Stanislava Mannova for excellent technical assistance. This work was supported by grant MSM0021622402 and by Centre of Excellence for Cardiovascular Research, Slovak Academy of Sciences.

\section{References}

Antzelevitch C. (2007): Ionic, molecular, and cellular bases of QTinterval prolongation and torsade de pointes. Europace 9 (Suppl. 4), iv4-15; doi:10.1093/europace/eum166

Antzelevitch C., Sicouri S., Litovsky S. H., Lukas A., Krishnan S. C., Di Diego J. M., Gintant G. A., Liu D. W. (1991): Heterogeneity within the ventricular wall. Electrophysiology and pharmacology of epicardial, endocardial, and M cells. Circ. Res. 69, 1427-1449

Arlock P., Gullberg B., Olsson S. R. (1978): Cardiac electrophysiology of four neuroleptics: melperone, haloperidol, thioridazine and chlorpromazine. Naunyn Schmiedebergs Arch. Pharmacol. 304, 27-36; doi:10.1007/ BF00501374

Baptista T., Kin N. M., Beaulieu S., de Baptista E. A. (2002): Obesity and related metabolic abnormalities during antipsychotic drug administration: mechanisms, management and research perspectives. Pharmacopsychiatry 35, 205-219; doi:10.1055/s-2002-36391

Bebarova M., Matejovic P., Pasek M., Novakova M. (2006): Effect of haloperidol on transient outward potassium current in rat ventricular myocytes. Eur. J. Pharmacol. 550, 15-23; doi:10.1016/j.ejphar.2006.08.046
Cheng L. F., Yan D., Turdi S., Kerram P. (2007): Biphasic effects of haloperidol on sodium currents in guinea pig ventricular myocytes. Acta Pharmacol. Sin. 28, 783-788; doi:10.1111/ j.1745-7254.2007.00575.x

Crumb W. J. Jr., Ekins S., Sarazan R. D., Wikel J. H., Wrighton S. A., Carlson C., Beasley C. M. Jr. (2006): Effects of antipsychotic drugs on $\mathrm{I}_{\mathrm{to}}, \mathrm{I}_{\mathrm{Na}}, \mathrm{I}_{\text {sus }}, \mathrm{I}_{\mathrm{K} 1}$, and hERG: QT prolongation, structure activity relationship, and network analysis. Pharm. Res. 23, 1133-1143; doi:10.1007/s11095006-0070-7

Fletcher E. J., Church J., MacDonald J. F. (1994): Haloperidol blocks voltage-activated $\mathrm{Ca}^{2+}$ channels in hippocampal neurones. Eur. J. Pharmacol. 267, 249-252; doi:10.1016/09224106(94)90178-3

Gil-ad I., Shtaif B., Shiloh R., Weizman A. (2001): Evaluation of the neurotoxic activity of typical and atypical neuroleptics: relevance to iatrogenic extrapyramidal symptoms. Cell. Mol. Neurobiol. 21, 705-716; doi:10.1023/A:1015152021192

Hassaballa H. A., Balk R. A. (2003): Torsade de pointes associated with the administration of intravenous haloperidol: a review of the literature and practical guidelines for use. Expert Opin. Drug Saf. 2, 543-547

Huang Z. Q., Shi G. G., Zheng J. H., Liu B. (2003): Effects of N$n$-butyl haloperidol iodide on rat myocardial ischemia and reperfusion injury and L-type calcium current. Acta Pharmacol. Sin. 24, 757-763

Huang Z., Shi G., Gao F., Zhang Y., Liu X., Christopher T. A., Lopez B., Ma X. (2007): Effects of N-n-butyl haloperidol iodide on L-type calcium channels and intracellular free calcium in rat ventricular myocytes. Biochem. Cell. Biol. 85, 182-188; doi:10.1139/O07-012

Ito K., Nakazawa K., Koizumi S., Liu M., Takeuchi K., Hashimoto T., Ohno Y., Inoue K. (1996): Inhibition by antipsychotic drugs of L-type $\mathrm{Ca}^{2+}$ channel current in PC12 cells. Eur. J. Pharmacol. 314, 143-150; doi:10.1016/S00142999(96)00500-6

Jann M. W., Crabtree B. L., Pitts W. M., Lam Y. W., Carter J. G. (1997): Plasma alpha-one acid glycoprotein and haloperidol concentrations in schizophrenic patients. Neuropsychobiology 36, 32-36; doi:10.1159/000119357

Javaid J. I., Janicak P. G., Sharma R. P., Leach A. M., Davis J. M., Wang Z. (1996): Prediction of haloperidol steady-state levels in plasma after a single test dose. J. Clin. Psychopharmacol. 16, 45-50; doi:10.1097/00004714-199602000-00008

Kornhuber J., Schultz A., Wiltfang J., Meineke I., Gleiter C. H., Zochling R., Boissl K. W., Leblhuber F., Riederer P. (1999): Persistence of haloperidol in human brain tissue. Am. J. Psychiatry 156, 885-890

Kriwisky M., Perry G. Y., Tarchitsky D., Gutman Y., Kishon Y. (1990): Haloperidol-induced torsades de pointes. Chest 98, 482-484; doi:10.1378/chest.98.2.482

Lacinova L., Hofmann F. (1998): Isradipine interacts with the open state of the L-type calcium channel at high concentrations. Recept. Channels 6, 153-164

Lacinova L., Klugbauer N., Hofmann F. (2000): State- and isoformdependent interaction of isradipine with the $\alpha_{1 C}$ L-type calcium channel. Pflügers Arch. 440, 50-60; doi:10.1007/ s004249900244 
Lacinová L' (2005): Voltage-dependent calcium channels. Gen. Physiol. Biophys. 24 (Suppl. 1), 1-78

Lacinova L., Moosmang S., Langwieser N., Hofmann F., Kleppisch T. (2008): $\mathrm{Ca}_{\mathrm{v}} 1.2$ calcium channels modulate the spiking pattern of hippocampal pyramidal cells. Life Sci. 82, 41-49; doi:10.1016/j.lfs.2007.10.009

Martin R. L., McDermott J. S., Salmen H. J., Palmatier J., Cox B. F., Gintant G. A. (2004): The utility of hERG and repolarization assays in evaluating delayed cardiac repolarization: influence of multi-channel block. J. Cardiovasc. Pharmacol. 43, 369-379; doi:10.1097/00005344-20040300000007

Mehta D., Mehta S., Petit J., Shriner W. (1979): Cardiac arrhythmia and haloperidol. Am. J. Psychiatry 136, 1468-1469

Natali A. J., Wilson L. A., Peckham M., Turner D. L., Harrison S. M., White E. (2002): Different regional effects of voluntary exercise on the mechanical and electrical properties of rat ventricular myocytes. J. Physiol. 541, 863-875; doi:10.1113/jphysiol.2001.013415

Noguchi K., Karasawa Y., Isobe Y., Fukushima K., Tanaka H., Shigenobu K. (1999): The effects of haloperidol on action potential parameters of isolated rabbit ventricular muscle. Res. Comm. Biol. Psychol. Psychiatr. 24, 21-33

Ogata N., Narahashi T. (1989): Block of sodium channels by psychotropic drugs in single guinea-pig cardiac myocytes. Br. J. Pharmacol. 97, 905-913

Rasty S., Amin N. B., Sabbah H. N., Mishima T., Borzak S., Tisdale J. E. (2004): Influence of i.v. haloperidol on ventricular repolarization and monophasic action potential duration in anesthetized dogs. Chest 125, 1821-1829; doi:10.1378/ chest.125.5.1821

Settle E. C. Jr., Ayd F. J. Jr. (1983): Haloperidol: a quarter century of experience. J. Clin. Psychiatry 44, 440-448

Sugiyama A., Satoh Y., Hashimoto K. (2001): In vivo canine model comparison of cardiohemodynamic and electrophysiological effects of a new antipsychotic drug aripiprazole (OPC-14597) to haloperidol. Toxicol. Appl. Pharmacol. 173, 120-128; doi:10.1006/taap.2001.9168

Ulrich S., Wurthmann C., Brosz M., Meyer F. P. (1998): The relationship between serum concentration and therapeutic effect of haloperidol in patients with acute schizophrenia. Clin. Pharmacokinet. 34, 227-263; doi:10.2165/00003088199834030-00005

Welling A., Kwan Y. W., Bosse E., Flockerzi V., Hofmann F., Kass R. S. (1993): Subunit-dependent modulation of recombinant L-type calcium channels. Molecular basis for dihydropyridine tissue selectivity. Circ. Res. 73, 974-980

Wirshing D. A., Boyd J. A., Meng L. R., Ballon J. S., Marder S. R., Wirshing W. C. (2002): The effects of novel antipsychotics on glucose and lipid levels. J. Clin. Psychiatry 63, 856-865

Yang S. B., Proks P., Ashcroft F. M., Rupnik M. (2004): Inhibition of ATP-sensitive potassium channels by haloperidol. Br. J. Pharmacol. 143, 960-967; doi:10.1038/sj.bjp.0706017

Zhang H., Cuevas J. (2002): Sigma receptors inhibit high-voltageactivated calcium channels in rat sympathetic and parasympathetic neurons. J. Neurophysiol. 87, 2867-2879

Received: October 8, 2008

Final version accepted: March 3, 2009 